\title{
STRATEGI KESANTUNAN BERBAHASA DALAM PEMBELAJARAN BAHASA INDONESIA
}

\author{
Kartika Ken Kusumaswarih \\ Universitas Muhammadiyah Jember \\ ken.kusumaswarih14@gmail.com
}

\begin{abstract}
ABSTRAK
Strategi kesantunan adalah upaya penutur dalam mengekspresikan kesantunannya dalam wujud bahasa. Pembelajaran di sekolah harus menerapkan strategi kesantunan baik oleh guru maupun siswa, agar proses komunikasi berjalan dengan lancar. Penelitian ini bertujuan untuk mendeskripsikan penggunaan strategi kesantunan berbahasa dalam pembelajaran bahasa Indonesia di SMA Negeri Pakusari. Jenis penelitian ini adalah kualitatif. Lokasi penelitian dilakukaan di SMA Negeri Pakusari di kelas X MIPA 2 dan X MIPA 4. Pengumpulan data dilakukan dengan cara menyimak, merekam, mencatat dan mengidentifikasi. Instrument yang digunakan dalam penelitian ini adalah rekaman video pembelajaran dan blangko pengodean (Coding Form). Data yang telah dikumpulkan dianalisis menggunakan metode padan dengan menggunakan teknik pilah unsur penentu selanjutnya menggunakan teknik lanjutan yaitu teknik baca markah. Hasil penelitian ini ditemukan penggunaan strategi kesantunan berbahasa yaitu, melakukan tindak tutur secara terus terang (on record), melakukan tindak tutur secara basa-basi (off record), kesantunan positif, dan kesantunan negatif. Selain empat strategi kesantunan berbahasa yang terdapat pada masalah penelitian, ditemukan strategi lain. Strategi tersebut berupa penggunaan dua strategi kesantunan berbahasa dalam satu tuturan. Strategi tersebut yaitu, melakukan tindak tutur secara terus terang dan kesantunan positif, melakukan tindak tutur secara terus terang dan kesantunan negatif. Berdasarkan hasil tersebut, simpulan dari penelitian ini yaitu keempat strategi kesantunan berbahasa sesuai dengan teori Brown dan Levinson telah digunakan dalam pertuturan pada pembelajaraan bahasa Indonesia.
\end{abstract}

Kata Kunci: pembelajaran bahasa Indonesia, strategi kesantunan berbahasa

\begin{abstract}
The politeness strategy refers to the speaker's effort in expressing her politeness in the form of language. In school learning context, this strategy should be applied by both teachers and students to ensure that the communication process among them can run smoothly. This qualitative research aims to investigate the use of language politeness strategy in learning Indonesian at X MIPA 2 and X MIPA SMA Negeri Pakusari. The data were collected through listening, recording, note taking, and identifying. Instruments used in this research are video recording of the learning process and coding form. The data were analyzed by using matching method utilizing the subdivision technique as well as marked reading technique. The results of analysis show the use of politeness strategy. First, they were done both on record and off record, and they use both positive and negative politeness strategies. In addition, other strategies were also used. The strategies were the combination of the positive and negative politeness strategies done on record in one speech act. The results showed that the strategies found in the research were in line with the theory of language learning by Brown and Levinson.
\end{abstract}

Keywords: language politeness strategy, Indonesian language learning 
Jurnal Belajar Bahasa, ISSN 2502-5864, E-ISSN 2503-0329

Volume 3, No. 2, September 2018

\section{PENDAHULUAN}

Kesantunan merupakan kajian penggunaan bahasa dalam suatu masyarakat tertentu (Rahardi, 2008, hal. 35). Menurut Leech kesantunan memiliki derajat yang berbeda, derajat kesantunan berbahasa menyangkut tiga skala, yakni skala untung rugi, skala opsionalitas, dan skala ketak-langsungan. Kesantunan berbahasa pada dasarnya adalah sebuah upaya penyelamatan muka(Andianto, 2013, hal. 56). Ditegaskan pada konsep Brown dan Levinson bahwa muka pada hakikatnya menunjuk pada harga diri seseorang (Nadar, 2009, hal. 32). Terdapat dua tipe yaitu muka positif dan muka negatif seseorang. Muka positif adalah keinginan setiap penutur agar dapat diterima atau disenangi oleh pihak lain. Muka negatif adalah keinginan individu agar setiap keinginananya tidak dihalangi oleh orang lain.

Tindak tutur tertentu secara alamiah dapat menjadi tindakan yang tidak menyenangkan yang disebut dengan face threatening act (tindak pengancaman muka). Cara yang digunakan untuk menghindari tindak pengancaman muka yaitu dengan menggunakan strategistrategi tertentu. Strategi tersebut digunakan untuk mengurangi resiko akibat tuturan yang kurang menyenangkan. Penutur hendaknya menggunakan strategi kesan-tunan untuk mengurangi ancaman terhadap lawan tutur.

Strategi kesantunan adalah cara yang digunakan oleh seorang penutur dalam rangka mengurangi akibat yang tidak menyenangkan dari tuturannya terhadap lawan tuturnya. Brown dan Levinson (da- lam Djatmika, 2016, hal. 79) menyajikan beberapa formula yang dikaitkan dengan konsep muka positif, muka negatif, dan tindakan yang mengancam muka yaitu strategi melakukan tindak tutur secara terus terang (bald on), melakukan tindak tutur secara basa-basi(off record), kesantunan positif, dan kesantunan negatif.

Strategi kesantunan ber-bahasa akan memperkecil kemungkinan untuk penutur memperoleh ancaman terhadap muka lawan tuturnya. Strategi kesantunan tersebut digunakan agar proses komunikasi dapat berjalan dengan lancar dan harmonis. Strategi kesantunan digunakan dalam proses belajar mengajar di dalam kelas.

Proses belajar mengajar ialah sebuah kegiatan antara siswa sebagai pelajar yang sedang belajar dengan guru sebagai pengajar yang sedang mengajar. Hubungan timbal balik dalam proses pembelajaranterjadi interaksi resiprokal yakni hubungan antara guru dengan para siswa dalam situasi instruksional, yaitu suasana yang bersifat pengajaran (Supriyadi, 2013, hal. 54).

Kesantunan berbahasa berasal dari tuturan dari seorang guru kepada siswa ataupun siswa kepada rekan sesamanya. Konsep muka dalam proses pembelajaran memiliki peran penting. Guru maupun siswa memiliki kemugkinan terhadap ancaman muka negatif dan muka positif lawan tutur. Muka positif guru dapat terancam, disebabkan oleh pertanyaan yang diajukan oleh siswa yang berisi kritik, pernyataan tidak setuju, dan tuduhan. Muka negatif siswa dapat terancam juga 
Jurnal Belajar Bahasa, ISSN 2502-5864, E-ISSN 2503-0329

Volume 3, No. 2, September 2018

karena tuturan guru yang berisi perintah, peringatan, nasehat, dan ancaman.

Peneliti bermaksud mem-bahas tuturan yang terdapat pada proses interaksi belajar mengajar di dalam kelas pada pembelajaran Bahasa Indonesia yang dilakukan di sekolah SMA Negeri Pakusari. Penentuan lokasi penelitian di sekolah tersebut berdasarkan asumsi bahwa strategi kesantunan berbahasa digunakan dalam pertuturan di SMA Negeri Pakusari. Penelitian di sekolah tersebut bertujuan agar peneliti dapat mengetahui bagaimana realisasi penggunaan strategi kesantunan berbahasa dalam interaksi guru dan siswa khususnya pada sekolah yang bukan berbasis sekolah islam/pesantren, karena di sekolah yang berbasis islam/pesantren kesantunan berbahasa harus diwujudkan dan diwajibkan pula berperilaku santun. Oleh karena itu peneliti mengangkat masalah yang diteliti yaitu bagaimanakah penggunaan Strategi Kesantunan Berbahasa dalam Pembelajaran Bahasa Indonesia SMA Negeri Pakusari? Fokus penelitian ini yaitu penggunaan strategi kesantunan berbahasa dengan menggunakan Brown dan Levinson.

Teori yang digunakan dalam penelitian ini adalah strategi kesantunan berbahasa menurut Brown dan Levinson. Strategi kesantunan merupakan usaha berperilaku santun dalam wujud bahasa. Brown dan Levinson menyajikan beberapa formula yang dikaitkan dengan konsep muka positif, muka negatif, dan tindakan yang mengancam muka yaitu strategi terus terang (on record), basa-basi (off record), kesantunan positif, kesantunan negativ (Djatmika, 2016, hal. 79).

\section{METODE PENELITIAN}

Penelitian kualitatif menurut Bogdan dan Taylor merupakan penelitian yang menghasilkan data deskriptif berupa katakata tertulis atau lisan dari orang-orang dan perilaku yang dapat diamati (Prastowo, 2011, hal. 22). Penelitian ini mendeskripsikan penggunaan strategi kesantunan berbahasa yang digunakan oleh guru dan siswa pada kegiatan pembelajaran Bahasa Indonesia di SMA Negeri Pakusari. Peneliti menguraikan hasil penelitian secara rinci sesuai dengan masalah yang diteliti dan menguraikan data berdasarkan apa yang ditemukan dalam penelitian. Penelitian ini dilaksanakan di SMA Negeri Pakusari

Data yang dikumpulkan dalam penelitian kualitatif lebih bersifat kualitatif yang mendeskripsikan setting penelitian, baik situasi maupu informan/responden yang umumnya berbentuk narasi melalui perantara lisan seperti ucapan/penjelasan respoden, dokumen pribadi, ataupun catatan lapang (Suharsaputra, 2014, hal. 188). Data yang digunakan dalam penelitian ini adalah tuturan berupa kata-kata, frasa, dan kalimat yang terindikasi di strategi kesantunan berbahasa yang diucapkan guru dan siswa pada kegiatan pembelajaran Bahasa Indonesia kelas X MIPA 2 dan X MIPA 4 SMA Negeri Pakusari.

Teknik pengumpulan data yang digunakan dalam penelitian ini yaitu teknik simak, peneliti menyimak pertuturan yang terjadi dalam pembelajaran Bahasa Indonesia, sembari menyimaak peneliti merekam selama kegiatan pembelajaaran 
Jurnal Belajar Bahasa, ISSN 2502-5864, E-ISSN 2503-0329

Volume 3, No. 2, September 2018

terjadi penggunakan handycam dan telepon genggam. Teknik selanjutnyaa yaitu catat, peneliti mencatat tuturan dengan cara mengubah tuturan lisan kedalam bentuk bahasa tulis. Selanjutnya peneliti mengklasifikasi. Instrumen utama dalam penelitian kualitatif adalah peneliti sendiri. Adapun instrument penunjang yang peneliti gunakan yaitu rekaman video dan blangko pengodean (coding form).

Peneliti menggunakan metode padan untuk menganaliis data dalam penelitian ini.Metode padan, alat penentunya di luar, terlepas, dan tidak menjadi bagian dari bahasa yang bersangkutan (Sudaryanto, 2015, hal. 15). Sub-jenis metode yang digunakan adalah metode pragmatis. Metode pragmatis alat penentunya berupa mitra wicara atau mitra tutur.

Peneliti menggunakan Teknik dasar dalam metode padan yaitu teknik pilah unsur penentu atau teknik PUP. Teknik lanjutan yang digunakan dalam metode ini adalah teknik baca markah. Pemarkah tersebut menunjukkan kejatian satuan lingual atau identitas konstituen tertentu. Setiap strategi kesantunan berbahasa mempunyai ciri khas tersendiri yang menjadi identitas strategi tersebut.

Peneliti melakukan analisis dengan melihat markah untuk strategi kesantunan berbahasa. Langkah-langkah dari metode baca markah tersebut dalam praktiknya dilakukan oleh peneliti setelah merekam percakapan dengan bahasa lisan dan kemudian menyalinnya dalam bahasa tulis. Data yang telah dipilah-pilah atau diidentifikasi, selanjutnya dianalisis berdasarkan pemarkah dalam strategi kesantunan berbahasa.
Pengecekan keabsahan data pada penelitian ini dengan cara meningkatkan ketekunan dan triangulasi. Pelaksanaan didasarkan atas sejumlah kriteria tertentu (Moleong, 2012, hal. 324). Pengujian keabsahan data memeliki maksud untuk memeperoleh data yang dapat dipertanggungjawabkan.

\section{PEMBAHASAN}

Teori yang digunakan dalam penelitian ini adalah strategi kesantunan berbahasa menurut Brown dan Levinson. Strategi kesantunan merupakan usaha berperilaku santun dalam wujud bahasa. Brown dan Levinson menyajikan beberapa formula yang dikaitkan dengan konsep muka positif, muka negatif, dan tindakan yang mengancam muka yaitu strategi terus terang (on record), basa-basi (off record), kesantunan positif, kesantunan negatif (Djatmika, 2016, hal. 79).

Penelitian mengenai strategi kesantunan berbahasa telah dilakukan sebelumnya, salah satu penelittin yang relevan dengan penelitian ini yaitu penelitian yang berjudul "Strategi Kesantunan Tuturan Guru Dalam Interaksi Pembelajaran Di Sma Negeri 4 Kota Malang". Penelitian ini membahas mengenai penggunaan tuturan guru Bahasa Indonesia dalam interaksi pembelajaran di SMAN 4 Kota Malang(Wijanarko, 2014). Hasil penelitian ini menemukan bahwa tuturan guru dalam interaksi pembelajaran Bahasa Indonesia menggunakan strategi kesantunan positif, strategi kesantunan negatif dan strategi kesantunan tidak langsung. Strategi tersebut ditemukan pada ke- 
Jurnal Belajar Bahasa, ISSN 2502-5864, E-ISSN 2503-0329

Volume 3, No. 2, September 2018

giatan awal, kegiatan inti, dan kegiatan akhir pembelajaran.

Berdasarkan penelitian yang telah dilakukan, strategi kesantunan terindikasi digunakan pada per-tuturan pembelajaran bahasa Indonesia di SMA Negeri Pakusari. Strategi kesantunan yang ditemukan yaitu, melakukan tindak tutur secara terus terang (on record), kesantunan positif, kesantunan negatif, me-lakukan tindak tutur secara basa-basi (off record), melakukan tindak tutur secara terus terang (on record) dan kesantunan positif, melakukan tindak tutur secara terus terang (on record) dan kesantunan negatif.

\section{A. Penggunaan Strategi Terus Terang (On Record)}

Menurut Brown dan Levinson melakukan tindakan secara terus terang tanpa berupaya untuk menyelamatkaan muka lawan tutur berarti melakukan tindakan tersebut secara langsung, jelas, tegas dan ringkas. strategi tindak tutur secara terus terang digunakan oleh penutur yang mempunyai kedudukan atau kekuasaan yang lebih tinggi dari lawan tutur. Karena itu guru dapat menggunakan strategi berterus terang karena mempunyai kedudukan atau kekuasaan yang lebih tinggi dari siswa. Penggunaan strategi terus terang diwujudkan dengan penggunaan tuturan perintah dan nasihat. Tuturan perintah dan nasihat yang diucapkan oleh penutur dapat dikatakan santun karena penutur menggunakan tuturan silahkan dan minta tolong kepada lawan tutur. Berikut data yang terindikasi strategi terus terang (on record).
Data 1

GR : Sudah semua? Sudah silahkan buka $K D$ yang ke dua yaitu mendemonstrasikan puisi

SW : Halaman berapa bu?

Data (1) pada pertuturan GR terindikasi sebagai penggunaan strategi kesantunan berbahasa. Penutur mengungkapkan Sudah silahkan buka KD yang ke dua yaitu mendemonstrasikan puisi kepada lawan tutur. Tuturan perintah langsung merupakan pemarkah dari strategi terus terang (on record).

Penutur menggunakan kata silahkan dalam memerintah. Tuturan dengan kata silahkan akan terdengar lebih santun dibandingkan dengan peritah langsung dengan tuturan buka KD yang ke dua yaitu men-demonstrasikan puisi. Oleh karena itu penggunaan kata silahkan menjadi-kan perintah yang diutarakan penutur terdengar santun dan untuk menghindari ke-mungkinan terjadinya kesalahpahaman.

\section{B. Penggunaan Strategi Basa-Basi (Off Record)}

Brown dan Levinson menyatakan bahwa strategi basa-basi (off record) digunakan dengan membuat tuturan lebih dari satu penafsiran sehingga penutur dianggap tidak bertanggung jawab sepenuhnya terhadap tujuan dan maksud dari tuturannya. Strategi tersebut direalisasikan dengan penggunaan metafora, perumpamaan, penyederhanaan masalah, dan ungkapan yang diungkapkan secara tidak langsung oleh penutur. Berikut ini 
Jurnal Belajar Bahasa, ISSN 2502-5864, E-ISSN 2503-0329

Volume 3, No. 2, September 2018

merupakan data yang terindikasi strategi basa-basi (off record).

Data 2

GR: Rif belajar puasa bicara ya. Temannya begini lansung begini. Puasa bicara ini salah satu nasihat seorang sastrawan. Ketika kamu ingin mengarang berbica kamu. Lakukan puasa berbicara. Yang baca siapa?

Data (2) pada pertuturan GR terindikasi sebagai penggunaan strategi kesantunan berbahasa. Penutur menggunakan tuturan metafora. Penggunaan metafora merupakan pemarkah dari strategi basa-basi. Tuturan tersebut dibuktikan dengan tuturan Rif belajar puasa bicara ya. Penutur bermaksud untuk menasihati lawan tutur untuk tidak banyak bicara. Jika penutur mengatakan secara langsung nasihat yang dimaksudkan dengan tuturan Jangan Bicara! maka tuturan tersebut tidak santun. Oleh karena itu penutur menggunakan ungkapan yang bukan arti sebenarnya atau metafora. Penggunaan metafora membuat tuturan nasihat terasa lebih santun dan mudah diterima oleh lawan tutur.

\section{Penggunaan Strategi Kesantunan Positif}

Strategi kesantunan positif digunakan untuk menghindari ancaman muka positif. Sesuai dengan teori Brown dan Levinson bahwa terdapat lima belas bentuk strategi, beberapa bentuk strategi tersebut ditemukan dalam penelitian ini. Bentuk penggunaan strategi kesantunan positif antara lain, memberikan perhatian khusus pada lawan tutur, melebihkan ketertarikan terhadap lawan tutur, menggunakan penanda identitas kelompok, mengusahakan persetujuan dengan mengulang sebagian tuturan lawan tutur, menghindari ketidaksetujuan dengan pura-pura setuju, menggunakan kesamaan keadaan dengan lawan tutur, membuat lelucon, penawaran, berusaha melibatkan lawan tutur dan penutur dalam suatu kegiatan tertentu. dan bersikap optimis. Berikut data yang terindikasi strategi kesantunan positif.

Data 3

GR : Nak kamu bagusnya ada di vokal ya, ya betul ya? setuju ya?

SW : Ya.

GR : Betul ya? setuju ya? suara seraknya membantu semangat pembacaan puisi terebut.

Data (3) pada pertuturan GR terindikasi sebagai penggunaan strategi kesantunan berbahasa. Penutur menggunakan tuturan nak yang merupakan penanda identitas kelompok. Kemudian dalam tuturan berikutnya penutur berusaha mencari perseujuan dengan mengulang jawaban lawan tutur dengan bukti tuturan Betul ya setuju ya.

Penggunaan penanda identitas kelompok dan mengusahakan persetujuan dengan mengulang sebagian tuturan lawan tutur merupakan pemarkah dari strategi kesantunan positif. Penggunaan penanda identitas kelompok tersebut bartujuan untuk mendekatkan jarak antara penutur dengan lawan tutur. Mengusahakan persetujuan dengan mengulang sebagian tuturan lawan tutur bertujuan agar keputusan tidak berkesan secara sepihak. Dengan cara tersebut membuat lawan tutur merasa nyaman dan ikhlas 
Jurnal Belajar Bahasa, ISSN 2502-5864, E-ISSN 2503-0329

Volume 3, No. 2, September 2018

dengan keputusan, sehingga tuturan akan terasa lebih santun.

\section{Penggunaan Strategi Kesantunan Negatif}

Strategi kesantunan negatif digunakan untuk menghindari ancaman muka negatif. Penggunaan strategi tersebut ditemukan dilakukan dengan cara penutur mengakui, menghormati dan memberikan kebebasan bertindak kepada lawan tutur. Sesuai dengan teori Brown dan Levinson bahwa terdapat delapan bentuk strategi kesantunan negatif, beberapa bentuk strategi kesantunan negatif tersebut ditemukan dalam penelitian ini. Bentuk penggunaan strategi kesantunan negatif antara lain, menunjukkan rasa pesimis, menggunakan permohonan maaf dan bersifat lugas tapi tidak diarahkan oleh orang kedua. Berikut data yang terindikasi strategi kesantunan negatif.

Data 4

GR : Sekali lagi X IPA 2 Bu Maya sudah memperhatikan beberapa anak yang suka celometan. ini siapa namanya? SW : Sarif.

Data (4) pada pertuturan GR terindikasi sebagai penggunaan strategi kesantunan berbahasa. Tuturan tersebut dibuktikan dengan Sekali lagi X IPA 2 Bu Maya sudah memperhatikan beberapa anak yang suka celometan. ini siapa namanya.Tuturan tersebut sebenarnya ditujukan kepada satu orang saja yaitu kepada siswa yang celometan, namun penutur melibatkan seluruh kelas dalam pertuturannya. Tuturan langsung seperti Saya sudah memperhatikan kalau Sarif selalu celome- tan dapat menyinggung lawan tutur dan memper-malukannya. Oleh karena itu penutur menggunakan strategi kesantunan dengan tidak mengarahkan kepada lawan tutur secara langsung.Tuturan yang bersifat lugas namun tidak diarahkan ke lawan tutur secara langsung merupakan markah dalam startegi kesantunan negatif. Sehingga tuturan tersebut terkesan santun dan dapat mengindari ancaman muka negatif lawan tutur.

\section{E. Penggunaan Strategi Terus Terang (On Record) dan Strategi Kesantunan Pos- itif}

Penggunaan dua strategi kesantunan berbahasa dalam satu tuturan ditemukan dalam penelitian ini. Pengunaan strategi melakukan tindak tutur secara terus terang dilakukan dengan strategi kesantunan lain seperti strategi kesantunan positif dalam satu pertuturan. Sesuai dengan pendapat Brown dan Levinson bahwa jika penutur memutuskan untuk melakukan tindak tutur secara terus terang, penutur juga dapat mempertimbangkan langkahlangkah penyelamatan muka positif menggunakan strategi kesantunan positif. Bentuk tuturan dengan menggunakan dua strategi tersebut antara lain dengan tuturan perintah dan menggunakan penanda identitas kelompok, tuturan perintah dan tuturan yang melebihkan ketertarikan. Berikut data yang terindikasi strategi terus terang (on record) dan kesantunan positif.

\section{Data 5}

GR : Silahkan kalian analisisi tema suasana dan maknanya secara berke- 
Jurnal Belajar Bahasa, ISSN 2502-5864, E-ISSN 2503-0329

Volume 3, No. 2, September 2018

lompok sudah setelah kalian mengetahui tiga hal tersebut maka kalian bisa menganaliis isinya. Setelah kalian bisa menganalisis isinya maka kalian akan tahu cara membacanya. Ekspresinya suasananya harus bagaiamana

SW : Siap.

Data (5) merupakan penggunaan strategi terus terang. Penggunaan strategi tersebut dilakukan oleh $\mathrm{GR}$ pada saat memerintah SW. Data tersebut tergolong sebagai strategi terus terang karena penutur mempunyai kedudukan yang lebih tinggi daripada lawan tutur. Oleh karena itu penutur melakukan perintah secara langsung kepada lawan tutur, namun penutur menggunakan kata silahkan dalam memerintah. Penutur juga menggunakan tuturan yang menunjukkan keoptimisan.

Bersikap optimis merupakan markah yang menunjukkan tuturan tersebut merupakan strategi kesantunan positif, oleh karena itu betuk tuturan pada data diatas merupakan penggunaan strategi terus terang dan kesantunan positif. Tuturan optimis dibuktikan dengan penggunaan kalimat Setelah kalian bisa menganalis isinya maka kalian akan tahu cara membacanya. Penutur meyakini bahwa setelah memberikan perintah untuk menganalisis puisi, maka lawan tutur akan mengetahui cara membaca puisi. Meyakinkan lawan tutur dengan sikap optimis akan membuat tuturan menjadi santun.

\section{F. Penggunaan Strategi Terus Terang (On Record) dan Strategi Kesantunan Negatif}

Penggunaan dua strategi kesantunan sekaligus juga ditemukan yaitu dengan penggunaan strategi terus terang (on record) dan strategi kesanunan negatif. Bentuk tuturan dengan menggunakan dua strategi tersebut direalisasikan dengan tuturan perintah dengan meminimalkan beban lawan tutur. Berikut data yang terindikasi strategi terus terang (on record) dan kesantunan negatif.

Data 6

GR : Membaca puisi yang sudah disiapkan. Bu Maya minta satu anak yang membacakan, sebenarnya semuanya harus siap. Tapi bu maya minta. Minta siapa yang siap membacakan di depan satu anak satu saja. Biar kita sama-sama melihat. Ayo!

GR : Ayo sini!

SW : Saya bu.

GR : Oke silahkan.

Data (6) pada pertuturan GR terindikasi sebagai penggunaan strategi kesantunan berbahasa. Penggunaan strategi tersebut dilakukan oleh GR pada saat memerintah SW. perintah merupakan markah dari strategi terus terang. Strategi tersebut digunakan oleh penutur karena penutur mempunyai kedudukan yang lebih tinggi daripada lawan tutur. Oleh karena itu penutur melakukan perintah secara langsung kepada lawan tutur, penutur memerintah lawan tutur untuk maju membacakan puisi.

Penutur juga menggunakan tuturan yang bersifat lugas namun tidak diarahkan ke lawan tutur secara langsung. Tuturan yang bersifat lugas namun tidak diarahkan ke lawan tutur secara langsung merupakan markah dalam startegi kesantunan 
Jurnal Belajar Bahasa, ISSN 2502-5864, E-ISSN 2503-0329

Volume 3, No. 2, September 2018

negatif. Tuturan tersebut dibuktikan

dengan sebenarnya semuanya harussiap.

Maksud dari tuturan tersebut yaitu SW yang ditunjuk harus siap, namun penutur melibatkan seluruh kelas dalam pertuturannya. Tujuan dari tuturan tersebut agak lawan tutur yang dimaksudkan tidak tersinggung. Dengan tidak mengarahkan kepada lawan tutur secara langsung, maka tuturan tersebut terkesan santun dan dapat menghindari ancaman muka negatif lawan tutur.

Strategi kesantunan negatif juga ditunjukkan pada tuturan tapi bu maya minta. Minta siapa yang siap membacakan di depan satu anak satu saja. Tuturan tersebut merupakan tuturan yang meminimalkan beban lawan tutur. Dengan mengungkapkan satu saja, tuturan tersebut dapat mengurangi beban lawan tutur terhadap permintaan lawan tutur, sehingga tuturan terkesan santun.

\section{SIMPULAN}

Penggunaan strategi kesantunan berbahasa meliputi, strategi terus terang (on record), strategi basa-basi (off record), strategi kesantunan positif, strategi kesantunan negatif. Penelitian ini menemukan penggunaan dua strategi kesantunan berbahasa dalam satu tuturan yaitu, penggunaan strategi terus terang dan kesantunan positif dan penggunaan strategi terus terang dan kesantunan negatif. Strategi kesantunan yang cenderung digunakan yaitu strategi kesantunan positif yang digunakan oleh guru.

\section{DAFTAR RUJUKAN}

Andianto, M. R. (2013). Pragmatik Direktif dan Kesantunan Berbahasa. Yogyakarta: Gress Publishing.

Djatmika. (2016). Mengenal Pragmatik Yuk? Yogyakarta: Pustaka Pelajar.

Moleong, L. J. (2012). Metodologi Penelitian Kualitatif. Bandung: PT. Remaja Rosdakarya.

Nadar, F. (2009). Pragmatik \& Penelitian

Pragmatik. Yogyakarta: Graha IImu.

Prastowo, A. (2011). Metode Penelitian

Kualitatif dalam Prespektif Rancangan

Penelitian. Jogjakarta: AR-Ruzz Media.

Rahardi, R. K. (2008). Kesantunan

Imperatif Bahasa Indonesia. Jakarta:

Erlangga.

Sudaryanto. (2015). Metode dan Aneka

Teknik Analisis Data Pengantar

Penelitian Wahana Kebudayaan secara Linguistik. Yogyakarta: Shanata Dharma university Press.

Suharsaputra, U. (2014). Metode Penelitian Kuantitatif, Kualitatif, dan Tindakan. Bandung: PT Refika Aditama.

Supriyadi. (2013). Strategi Belajar \& Mengajar. Yogyakarta: Jaya Ilmu.

Wijanarko, J. (2014). Strategi Kesantunan

Tuturan Guru dalam Interaksi Pembelajaran di SMA Negeri 4 Kota Malang: dengan Sudut Pandang Teori Brown dan Levinson. Malang: Program Studi Pendidikan Bahasa, Sastra Indonesia dan Daerah Universitas Muhammadiyah. 